\title{
Large thymoma mass invading cardiac structures
}

\author{
Amer Harky, Mohamad Bashir, Ashok Kar, Alan Wood
}

Department of Cardiothoracic Hospital, London, UK

Correspondence to Amer Harky, dr_amerali@ hotmail.com

Accepted 9 November 2016 Surgery, Saint Bartholomew's

\section{DESCRIPTION}

We report a retired, Afro-Caribbean man aged 69 years who presented to his local hospital with several weeks of dyspnoea and cough. Physical examination was unremarkable apart from an elevated jugular venous pressure and a bilateral pedal oedema. His medical history included asthma and controlled hypertension. Urgent transthoracic echocardiography showed a large soft tissue mass in the pericardial space compressing the right ventricle (RV), and the right atrium (RA).

A CT of the thorax showed a mass measuring $16 \mathrm{~cm}$ in width by $8 \mathrm{~cm}$ in depth with infiltration and compression of RV and RA with distortion of atrioventricular groove anatomy between RV and RA (figure 1).

Cardiac MRI confirmed a large heterogeneous mass anterior to RV infiltrating its inferior wall and confirming a distorted local anatomy of the atrioventricular groove.

The patient underwent a CT-guided biopsy and the tissue confirmed the diagnosis of B2 thymoma. His case was discussed at joint cardiothoracic surgery and respiratory multidisciplinary meeting and it was agreed to schedule the patient for conventional thymectomy considering the size of the mass.

The patient underwent median sternotomy, which revealed a highly vascular tumour invading the pericardium and surrounding mediastinal structures. It also extended to the right lung, innominate vein, aorta, RA and RV. As it was difficult to delineate and isolate for radical removal, debulking of

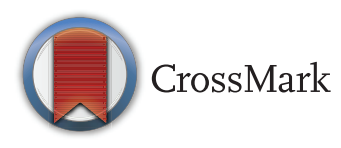

To cite: Harky A, Bashir M, Kar $\mathrm{A}$, et al. BMJ Case Rep Published online: [please include Day Month Year] doi:10.1136/bcr-2016218211
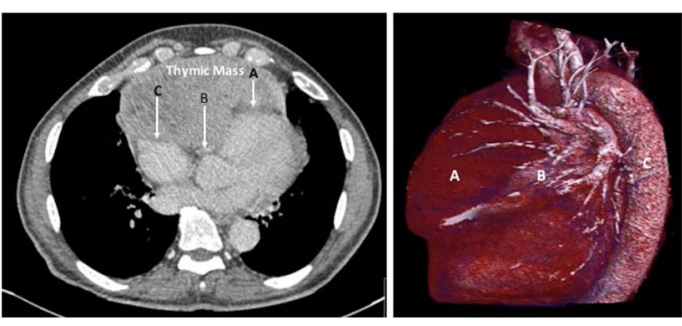

Figure 1 Contrast CT scan of the chest (left) showing thymoma mass invading the right ventricle (RV) (arrow A), invading the right coronary artery origin (arrow B) and invading the right atrium (arrow C).

Three-dimensional reconstruction of thymic mass and heart (right), (A) thymic mass infiltrating the heart and $\mathrm{RV},(\mathrm{B})$ pulmonary vasculature, (C) aorta.

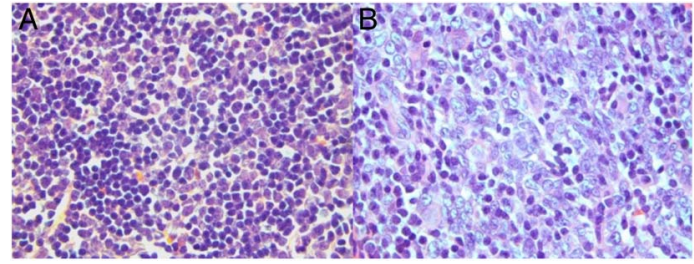

Figure 2 Histopathology slide showing fragments which are composed of thymoma which in areas shows a lymphoid dominant pattern B1 (A), while in the second slide (B) showing the epithelial-rich, lymphocyte-poor features of a B2 thymoma.

the mass was performed. Histopathology of the excised mass demonstrated a thymoma, of mixed pattern B1 and B2 (figure 2A, B).

Perioperatively, the patient remained stable and was sent to the high-dependency unit for postoperative recovery, his postoperative period was uneventful and he was discharged to his local hospital on day 21 postoperatively in stable health.

\section{Learning points}

- Although a rarity, thymomas can invade cardiac structures and patients may present with heart failure.

- Careful imaging assessment of the mediastinal mass is necessary prior to surgical intervention.

- MDT inclusion for quality decision-making is imperative in the management and surgical intervention.

- Not all thymomas are resectable and this is very dependent on the operator's experience and the extent of local invasion.

Acknowledgements The authors would like to acknowledge Dr Jonathan Colledge (Consultant Chest Radiologist) for his efforts to get us the right images to resubmit the case report.

Contributors $\mathrm{AH}$ prepared the first draft, reviewed and amended by $\mathrm{MB}$ and $\mathrm{AK}$ and finally approved by AW.

Competing interests None declared.

Patient consent Obtained.

Provenance and peer review Not commissioned; externally peer reviewed. 
Copyright 2016 BMJ Publishing Group. All rights reserved. For permission to reuse any of this content visit http://group.bmj.com/group/rights-licensing/permissions.

BMJ Case Report Fellows may re-use this article for personal use and teaching without any further permission.

Become a Fellow of BMJ Case Reports today and you can:

- Submit as many cases as you like

- Enjoy fast sympathetic peer review and rapid publication of accepted articles

- Access all the published articles

Re-use any of the published material for personal use and teaching without further permission

For information on Institutional Fellowships contact consortiasales@bmjgroup.com

Visit casereports.bmj.com for more articles like this and to become a Fellow 